Research, part of a Special Feature on A Systems Approach for Sustainable Development in Coastal Zones

\title{
Nitrogen Source Apportionment for the Catchment, Estuary, and Adjacent Coastal Waters of the River Scheldt
}

\author{
$\underline{\text { Jan E. Vermaat }}^{1}, \underline{\text { Steven Broekx }}^{2}, \underline{\text { Bert Van Eck }}^{3}, \underline{\text { Guy Engelen }}^{2}, \underline{\text { Fritz Hellmann }}^{4}, \underline{\text { Jean Luc De Kok }}^{2}$,

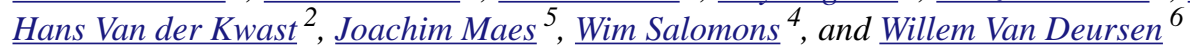

ABSTRACT. Using the systems approach framework (SAF), a coupled model suite was developed for simulating land-use decision making in response to nutrient abatement costs and water and nutrient fluxes in the hydrological network of the Scheldt River, and nutrient fluxes in the estuary and adjacent coastal sea. The purpose was to assess the efficiency of different longterm water quality improvement measures in current and future climate and societal settings, targeting nitrogen (N) load reduction. The spatial-dynamic model suite consists of two dynamically linked modules: PCRaster is used for the drainage network and is combined with ExtendSim modules for farming decision making and estuarine $\mathrm{N}$ dispersal. Model predictions of annual mean flow and total $\mathrm{N}$ concentrations compared well with data available for river and estuary $\left(r^{2} \geq 0.83\right)$. Source apportionment was carried out to societal sectors and administrative regions; both households and agriculture are the major sources of $\mathrm{N}$, with the regions of Flanders and Wallonia contributing most. Load reductions by different measures implemented in the model were comparable ( $\sim 5 \%$ remaining after $30 \mathrm{yr})$, but costs differed greatly. Increasing domestic sewage connectivity was more effective, at comparatively low cost (47\% remaining). The two climate scenarios did not lead to major differences in load compared with the business-as-usual scenario ( $\sim 88 \%$ remaining). Thus, this spatially explicit model of water flow and $\mathrm{N}$ fluxes in the Scheldt catchment can be used to compare different long-term policy options for $\mathrm{N}$ load reduction to river, estuary, and receiving sea in terms of their effectiveness, cost, and optimal location of implementation.

Key Words: catchment hydrology, coupled modeling, estuary, eutrophication, land use, systems analysis, watershed nutrient loading

\section{INTRODUCTION}

In coastal zones, highly contrasting habitats meet and biogeochemical processes interact, often leading to a combination of high productivity and biodiversity (Crossland et al. 2005) and conflicting uses. Humanity has concentrated its activities in coastal zones since the Paleolithic (Drake et al. 2011) and still does so today (Small and Nicholls 2003). In the second half of the 20th century, complex environmental problems manifested in these same narrow strips of transition area (Crossland et al. 2005). Societies throughout the world have struggled with these problems for a range of often interdependent reasons such as spatial separation of, and time lags between, effect and ultimate cause in human activities; multidisciplinary complexity; involvement across and outside national boundaries and jurisdictions; and imperfections in the science-policy interface, which should otherwise enable wellinformed policy implementation and management of the coastal zone. The latter issue in particular has been addressed through the application of the systems approach framework (SAF; Hopkins et al. 2011; http://www.coastal-saf.eu). The SAF approach requires a balanced consideration of the ecological, social, and economic (ESE) sectors that characterize coastal systems.
Our study traces nitrogen flows back to their sources in the Scheldt catchment because excessive loading is thought to have led to eutrophication of the estuary and adjacent coastal waters, with increased blooms of the nuisance alga Phaeocystis reported as a symptom (Billen et al. 2005, Breton et al. 2006, Lancelot et al. 2007). In line with the SAF procedure (Hopkins et al. 2011), stakeholder consultation helped us to focus on the policy issue of nitrogen apportionment and to evaluate different options to reduce nitrogen loading across the catchment. This also matches the finding of Lacroix et al. (2007) that policies aiming at reducing algal blooms in the Belgian coastal zone should target nitrogen loading. Our aim was to deploy and evaluate the SPICOSA SAF procedure in our development of a model suite (Lautenbach et al. 2009) to evaluate the effectiveness of different measures in a comprehensive and spatially explicit way for the whole Scheldt River basin. The Scheldt is a transboundary river; hence, the effects of measures in one country may not add linearly to those taken downstream. Also, soils vary considerably in water and nitrogen retention across regions (Behrendt and Opitz 1999, De Wit 2001); hence

\footnotetext{
${ }^{1}$ Earth Sciences and Economics, Faculty of Earth and Life Sciences, VU University, ${ }^{2}$ Flemish Institute for Technological Research (VITO), ${ }^{3}$ Deltares, ${ }^{4}$ Institute for Environmental Studies (IVM), VU University, ${ }^{5}$ Joint Research Centre-European Commission, ${ }^{6}$ PCRaster
} 
measure effectiveness will vary. This justifies our spatially explicit modeling of the catchment. A similar modeling exercise has been carried out for the adjacent Seine River by Ducharne et al. (2007), though without explicit stakeholder consultation or consideration of the coastal zone. In contrast, coastal models have generally lacked coverage of the terrestrial hinterland (Moll and Radach 2003, Lacroix et al. 2007).

Our model suite consists of a PCRaster-based drainage network coupled to a dynamic estuarine box model and a landuse model, both developed in EXTEND (ExtendSim). PCRaster (http://www.PCRaster.nl) has been used satisfactorily to model water and nutrient fluxes through a drainage network for several river basins (De Wit 2001, Pieterse et al. 2003, Mourad et al. 2006). A priori requirements for the model suite were: (1) to provide sufficient spatial resolution and representation of different types of land use included in the Scheldt basin; (2) to cover diffuse and point nutrient sources; (3) to include surface and groundwater flow; (4) to allow flexibility in the inclusion of different nutrient abatement measures; (5) to include economic land-use decisions by farmers, who can go bankrupt; (6) to include scenarios of climate change and possible future societal development such as those in the IPCC Special Report on Emissions Scenarios (SRES; Berkhout and Hertin 2000, Lorenzoni et al. 2000, Busch 2006, Van den Hurk et al. 2006, Verburg et al. 2006). The adoption of a scenario approach allows a flexible longerterm projection of contrasting but plausible future development trajectories. We distinguish management options and scenarios because the former are within reach of policy (here called measures), whereas the latter are longerterm and larger-scale global change trajectories (i.e., scenarios) that are much harder to influence by national policy or local management. Our model suite includes scenarios and measures and allows their combination.

To enhance policy relevance, we assess which measures would lead to an economically efficient achievement of a targeted reduction in total nitrogen concentration in the estuary and coastal sea. We use target criteria of the European Water Framework Directive (RBO Schelde 2008), i.e., 0.46 and 0.22 $\mathrm{mg} \mathrm{N} / \mathrm{L}$, respectively, as good ecological status and very good ecological status, for both estuarine and coastal waters. For the riverine section of the Scheldt, the corresponding standards are 4 and $3 \mathrm{mg} \mathrm{N} / \mathrm{L}$, respectively, for summer mean total nitrogen concentrations (CIW 2008). We compare the estimated loads from the Scheldt into the North Sea that result from a particular measure with those from the English Channel and the Seine, Thames, and Rhine rivers (Lacroix et al. 2007, Radach and Pätsch 2007).

\section{METHODS}

\section{Study area}

The coastal waters and estuary of the Scheldt River receive inputs from a catchment that is highly heterogeneous in occupation pattern and land-use intensity. Major urban centers of Antwerp, Brussels, Gent, Lille, and Mons alternate with mainly agricultural or peri-urban landscapes. Population density at the district level ranges from < 200 to 1000 inhabitants $/ \mathrm{km}^{2}$ (Billen et al. 2005, 2009). Agricultural land use is particularly intensive in Flanders and less so in northern France (Artois-Picardie), as indicated by cattle density and fertilization rates (respectively, > $100 \mathrm{vs}$. < 50 livestock units/ $\mathrm{km}^{2}$ and $\sim 300$ vs. $<100 \mathrm{~kg} \mathrm{~N} \mathrm{ha}^{-1} \mathrm{y}^{-1}$ of nitrogen balance surplus in the 1990s; De Walle and Sevenster 1998, Nevens et al. 2006, Billen et al. 2009). At the same time, the river's drainage network is engineered to accommodate various demands. The Scheldt has a length of $350 \mathrm{~km}$, its source is $100 \mathrm{~m}$ above sea level, and the mean freshwater discharge at the mouth is $150 \mathrm{~m}^{3} / \mathrm{s}$. The basin has an area of approximately $20,200 \mathrm{~km}^{2}$, which is shared by France, Belgium, and The Netherlands, each of which has a different institutional water management system. These countries cooperate in the International Scheldt Commission (ISC, http://www.isc-cie.org ). In around 1970, the water quality of the Scheldt was very poor, with annual oxygen depletion during summer and very high nutrient concentrations (Billen et al. 2005). Since 1980, the water quality has improved (Soetaert et al. 2006), notably because of increased domestic waste water treatment, but nutrient loads to the western Scheldt estuary and adjacent coastal North Sea are still considered high and a cause of eutrophication (Billen et al. 2005, Breton et al. 2006).

Adoption of the European Water Framework Directive (WFD) and the Marine Strategy Directive (Mee et al. 2008, RBO Schelde 2008) has led to the need to further reduce the nutrient load to river, estuary, and coastal waters. This reduction can be realized in various ways, and a range of potential measures is currently considered (CIW 2008) in conjunction with flood control. Local experiments are presently being monitored, including the inundation polders of Lippenbroek and Kruibeke (peak discharge flood control areas; Cox et al. 2006).

\section{Stakeholder consultation}

Institutional public sector stakeholder representatives from all countries sharing the catchment were consulted to decide upon the policy issue to be addressed during a one-day, open, structured brainstorming session on October 9, 2007. Public sector, commercial, and industrial stakeholders were derived from a long-list held by the ISC and were invited in writing to send a representative. Notably, authority representatives responded to the invitation. The SAF study site team prepared a long-list of 10 potentially relevant policy issues based on an 
internal review of the issues on the agenda of recent ISC meetings, local policy documents, and expert knowledge of the team. During the brainstorming session, participants were first introduced to the SAF approach and then allowed to reorganize the list or add new issues. This was followed by a discussion to clarify each issue and ensure its proper interpretation in a plenary round. Finally, a sticker-voting round was used to prioritize the issues. Votes of the SAF team and stakeholder representatives were tallied separately (Table 1 ), and the latter had precedence in our final choice. Two issues had high priority (Table 1), but climate-proofing was mainly voted for by SAF team members; hence, we adopted transboundary nitrogen apportionment as the major policy issue in this study. During the subsequent phase of model development, two progress consultations took place with the major institutional stakeholders responsible for water quality, i.e., the Vlaamse Milieu Maatschappij (VMM) for Flanders, Direction générale des Ressources naturelles et de l'Environnement (DGRNE) for Wallonia, Brussels Instituut voor Milieubeheer (BIM) for Brussels, the Waterdienst for the Netherlands, and the Agence de l'eau Artois Picardie for France. At the end of the project, the SAF team presented model outputs and interpretations to the stakeholders.

\section{Model development}

After reaching consensus on the thematic policy focus, we first set out to sketch conceptually (the design step in the SAF) and then articulate the model structure in terms of elements and linkages, spatial extent and resolution, and data requirements.

Table 1. Prioritizing policy issues addressed in the Scheldt River basin case. Each of the 17 participants had three votes to distribute.

\begin{tabular}{lccc}
\hline \hline Policy issue & $\begin{array}{c}\text { Votes: } \\
\text { study site } \\
\text { team }\end{array}$ & $\begin{array}{c}\text { Votes: } \\
\text { stakeholder } \\
\text { representat- } \\
\text { ives }\end{array}$ & $\begin{array}{c}\text { Total } \\
\text { votes }\end{array}$ \\
\hline $\begin{array}{l}\text { Seaward protection of the coast } \\
\text { Climate-proof water management }\end{array}$ & 0 & 0 & 0 \\
$\begin{array}{l}\text { How to solve transboundary issues in the } \\
\text { implementation of the EU Water }\end{array}$ & 3 & 6 & 13 \\
$\begin{array}{l}\text { Framework Directive } \\
\begin{array}{l}\text { Opportunities for aquaculture } \\
\text { Restoration of estuarine dynamics }\end{array}\end{array}$ & 3 & 12 & 15 \\
$\begin{array}{l}\text { How to accommodate wind parks, tidal } \\
\text { power plants, and marinas }\end{array}$ & 4 & 2 & 5 \\
$\begin{array}{l}\text { Future of the Antwerp-Rotterdam } \\
\text { shipping corridor }\end{array}$ & 1 & 4 & 3 \\
$\begin{array}{l}\text { Harbour expansion in the delta } \\
\text { How to accommodate urban overspill and } \\
\text { increasing mobility }\end{array}$ & 0 & 0 & 1 \\
\hline
\end{tabular}

This required a number of subsequent internal study team workshops. A complete formulation of the model suite was available by January 2009 in a documentation report for review as part of the SAF formulation step (see data portal at http:// www.spicosa.eu). During the subsequent calibration and verification phase, as part of the appraisal step in the SAF approach, it was necessary to reiterate some aspects of both the model structure and specific model formulations. In particular, the design of farming decision-making components and essential interface component to link up PCRaster with the simulation model in ExtendSim required repeated finetuning.

\section{Model suite structure}

The model suite combines a component-based simulation model in ExtendSim with a gridded hydrological PCRaster model of the full Scheldt catchment (Fig. 1, Table 2). The components have been designed to be reusable for other simulation studies (De Kok et al. 2010) and connect to a chain describing the income effect of nitrogen abatement, subsequent changes in allocation to different farm types, and dispersal of nitrogen in the western Scheldt estuary given the load at the river-estuary interface. Changes in the databases used by the components, including the type and number of categories, are automatically processed by the model. The ExtendSim module governs the progress of time and accommodates the general user interface with easy access to policy options, climate scenarios, simulation settings, and results.

For the PCRaster grid model, we closely followed the model structure of De Wit (2001) and Mourad et al. (2006), which estimates for each grid point the nitrogen flux due to diffuse and point sources into soil, subsoil, groundwater, and surface water. This is done using a temporal resolution of $1 \mathrm{yr}$ and a spatial resolution of $1 \mathrm{~km}^{2}$. The drainage network generated by PCRaster (Fig. 2) closely resembled the real-world network, with the exception of a highly altered and channelized section around the city of Gent, where we had to make some manual adjustments. The suite runs for the period 2008-2038 and reports the depth-averaged mean annual total nitrogen concentration and water flow as prime modeling output for a range of stations along the river and estuary. Further details on the development and use of the PCRaster component are provided by $\mathrm{H}$. Van der Kwast (personal communication; see also http://www.spicosa.eu).

Agricultural land-use decisions by farmers are modeled in ExtendSim in a separate farming economics module incorporating 10 different crop types, five livestock types, eight farm types, and five regions. Farm costs and benefits depend on market prices, manure levies, and transport costs. The profitability of a farm type is assessed in comparison with a reference income. Farms that make a loss are closed, and their land is redistributed. Manure and fertilizer use can generate a soil surface nitrogen surplus, which is partly routed to the surface water through the groundwater compartments 
Fig. 1. General structure of the model suite of water and nitrogen flowing through the Scheldt catchment, developed using PCRaster and ExtendSim. Policy measures and climate scenarios can be manipulated by the user.

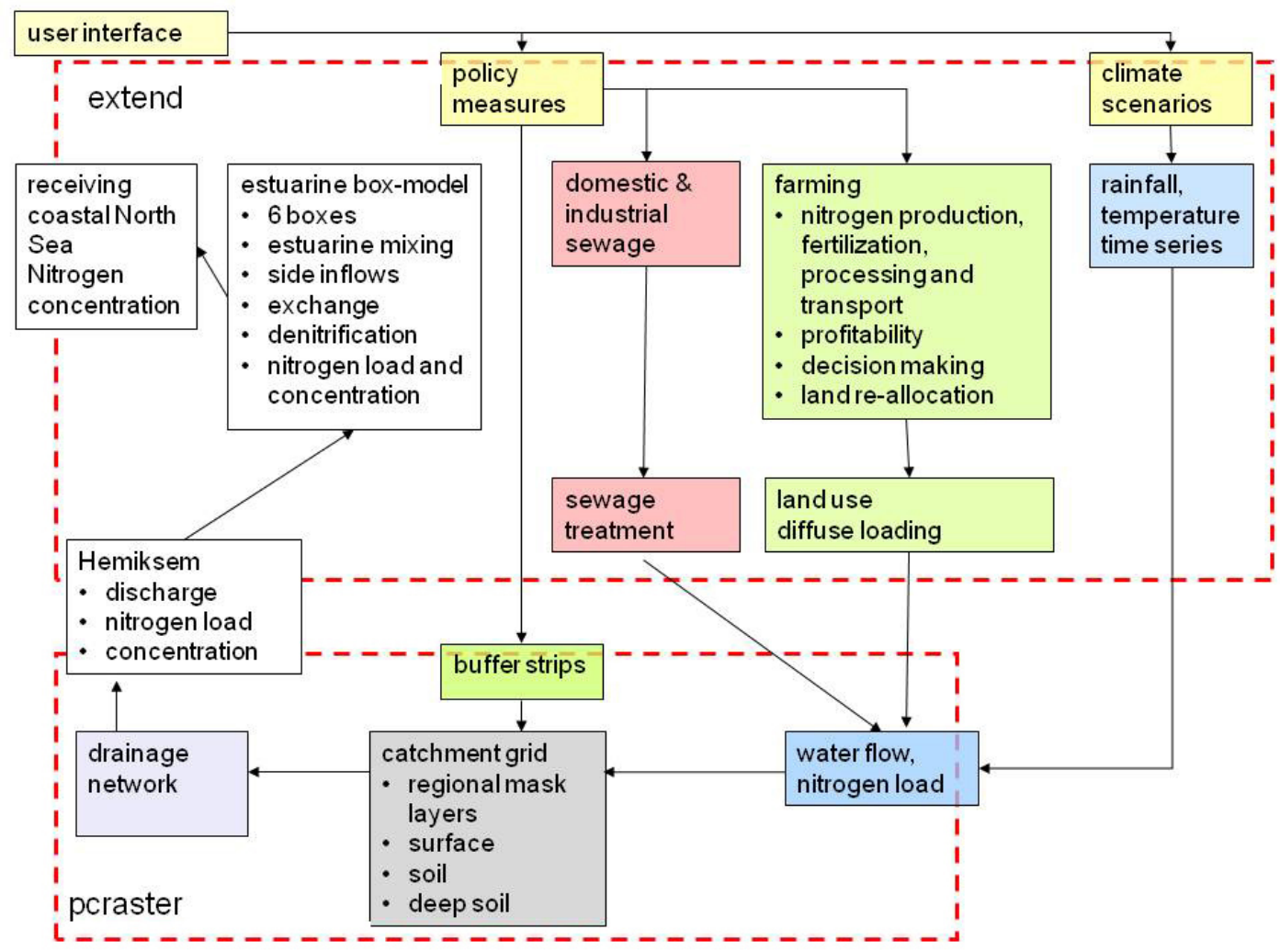

and compared with norms to signal the need to export manure or incur a fee. Start-up land allocation was allotted according to data provided by VMM. The agricultural model in ExtendSim runs at spatial units that combine sub-catchments and provinces. Land-use change data are forwarded to PCRaster as spatial masks to affect water flow and nitrogen processes as well as the routing downstream to Hemiksem (Fig. 1). Here, at the river-estuary boundary, the PCRaster output is passed to a simple ExtendSim estuarine box-chain model, with each box receiving side-inflows from sewage works effluent or polder outflows. Retention due to sedimentation and denitrification is pooled and modeled as a first-order process in each estuarine box. This does not match the complexity of estuarine nitrogen dynamics (see Soetaert et al. 2006) but is satisfactory at the annual time scale used here. Source apportionment is done at the start of the estuarine section (station Hemiksem, Fig. 2) and at the boundary between the estuary and the North Sea. Economic efficiency has been assessed by tentatively costing the different measures based on annualized investment costs at a set rate of $4 \%$ over a 20-yr period (Broekx and De Kok 2011).
Fig. 2. Scheldt catchment and its tributaries, as well as the locations of stations used for verification (Figs. 3 and 4). The station Hemiksem forms the transition from river to estuary.

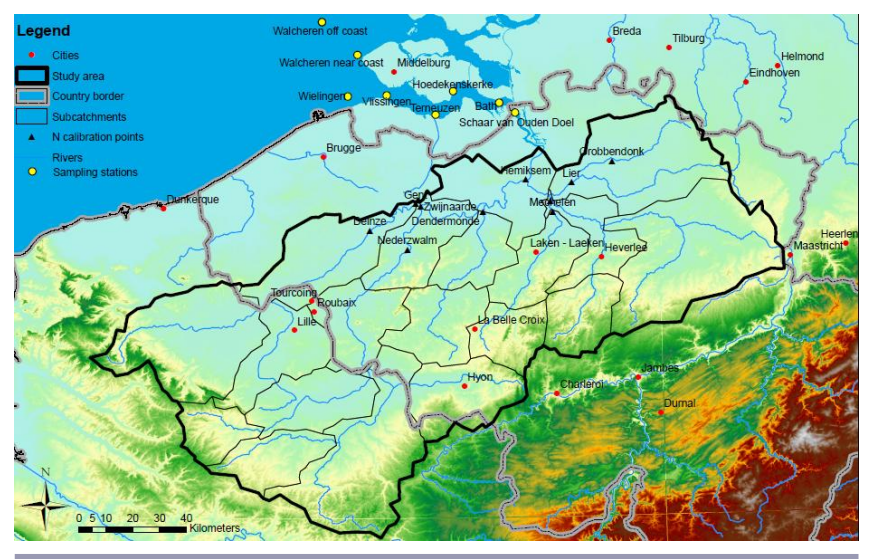


Table 2. Model suite modules and their main components, inputs, and outputs.

\begin{tabular}{|c|c|c|c|}
\hline Tool & Module & Inputs & Outputs \\
\hline PCRaster & $\begin{array}{l}\text { Grid layers of soil surface, soil, and subsoil; } \\
\text { hydrological network }\end{array}$ & $\begin{array}{l}\text { Annual rainfall, temperature, nitrogen } \\
\text { inputs from soil surface surplus }\end{array}$ & Discharge, nitrogen fluxes \\
\hline \multirow[t]{10}{*}{ ExtendSim } & Nitrogen production & Cattle density, crop area & $\begin{array}{l}\text { Nitrogen surplus; dairy, meat, and } \\
\text { crop production }\end{array}$ \\
\hline & Nitrogen abatement costs & $\begin{array}{l}\text { Nitrogen norm, nitrogen surplus, } \\
\text { production }\end{array}$ & Transport costs, processing costs \\
\hline & Farm income & Cattle, transport costs, processing costs & $\begin{array}{l}\text { Income per farm and per } \\
\text { employee }\end{array}$ \\
\hline & Income effect & Income per farm & Change in number of farms \\
\hline & Farm area reallocation & $\begin{array}{l}\text { Income per farm, number of farms, } \\
\text { change in number of farms }\end{array}$ & Area per farm \\
\hline & Source deposition standard & Nitrogen concentration & Nitrogen norm \\
\hline & Estuarine box model & $\begin{array}{l}\text { Upstream concentration, downstream } \\
\text { concentration }\end{array}$ & Box concentration \\
\hline & Climate change (generic scenario dialog) & Scenario 1990-2050 & $\begin{array}{l}\text { Annual precipitation, mean } \\
\text { temperature }\end{array}$ \\
\hline & Policy measure option (generic module) & $\begin{array}{l}\text { Start and end time, step size, path to } \\
\text { input file }\end{array}$ & $\begin{array}{l}\text { Various, e.g., cattle stock } \\
\text { reduction, buffer strips, fertilizer } \\
\text { use, nitrogen concentration at } \\
\text { outflow point }\end{array}$ \\
\hline & Spatial-dynamic interface (generic module) & Time step & N/A \\
\hline
\end{tabular}

\section{Calibration and data sources}

Calibration of the PCRaster output was made against an extensive data set of flows and total nitrogen concentrations for a range of stations in France and Belgium, provided by DGRNE, BIM, Agence de l'eau Artois Picardie, and the VMM. Data sets for these stations are of variable length, and in the calibration, we used these time series from their start (1967-2004) up to 2007. In PCRaster, the discharge is modeled for the period 1940-2007. Total nitrogen data were available from 1999 onwards. The simulation model runs for the period 2008-2038. The output of the ExtendSim estuarine box-model for 2006 was compared with those in an existing data set available in WATERBASE (http://www.waterbase.nl ) and found to be satisfactory. Spatially explicit data on land use, population density, agricultural productivity, crops, livestock, fertilizer use, and urban sewerage connection were obtained from VMM, EUROSTAT, national statistics services, and internal databases of the Flemish Institute for Technological Research (Vlaams Instituut voor Technologisch Onderzoek; VITO). Cost data for wastewater treatment are mainly based on information from the different river basin management plans. Costs for agriculture are largely determined by region-specific standard gross margins for different animal and crop types reported in EUROSTAT. Costs are annualized at a set discount rate of $4 \%$ over $20 \mathrm{yr}$ (Broekx and De Kok 2011). Historical agricultural data were obtained from De Walle and Sevenster (1998).

\section{Scenarios and policy measures adopted}

Based on a separate assessment by Vermaat et al. (2009b), the SAF team adopted a coupling of SRES-societal change scenarios to meteorological climate change scenarios stipulated for the Netherlands and its surroundings by Van den Hurk et al. (2006). The latter offers synthetic time series of temperature and precipitation with daily time steps for each scenario, which are useful as standardized input for this and other modeling efforts (e.g., Te Linde et al. 2011). Van den Hurk et al. (2006) distinguish four scenarios based on divergences in temperature increase and westerly circulation. These are labeled G, G+, W, and W+, respectively, where G stands for a moderate and $\mathrm{W}$ for a stronger temperature and rainfall increase, and the + denotes a stronger westerly circulation. These climate scenarios have been equated, with some caution, to the SRES scenarios (for the Netherlands: Van den Hurk et al., 2006). The two most strongly contrasting scenarios, $\mathrm{G}$ and $\mathrm{W}+$, were included in the present model suite. These are taken to correspond roughly with two of the four SRES scenarios, B1 and A2 (Busch 2006). In the SRES exercise (Lorenzoni et al. 2000) and similar scenario development studies (Busch 2006), the world's socioeconomic development is deduced along two major dimensions: one of development between either self-interest or solidarity, and the other on whether the world is globally oriented or regionally focused. Briefly, the A2 scenario foresees a regionalized world of self-interest, whereas B1 describes a further globalizing world with a stress on solidarity. Particularly in the latter, environmental concern and a focus on sustainability is thought 
Table 3. Description of different policy measures presently incorporated in the Scheldt model suite.

\begin{tabular}{|c|c|c|}
\hline Policy measure & Description & Source for quantification \\
\hline (1) Business as usual & $\begin{array}{l}\text { Current land-use practice and increased manure processing plant investments are } \\
\text { included. }\end{array}$ & Broekx and De Kok (2010) \\
\hline $\begin{array}{l}\text { (2) } 50 \% \text { cattle stock } \\
\text { reduction }\end{array}$ & $\begin{array}{l}\text { Because agriculture is the major source of diffuse nutrient loading to the surface water } \\
\text { system, implementing a reduction in stocking density and nutrient application rates } \\
\text { will have an effect on nitrogen loading. }\end{array}$ & De Wit (2001), Pieterse et al. (2003) \\
\hline $\begin{array}{l}\text { (3) } 50 \% \text { reduction in } \\
\text { fertilizer and manure } \\
\text { applications }\end{array}$ & See (2) & \\
\hline $\begin{array}{l}\text { (4) } 40 \% \text { improvement in } \\
\text { waste water treatment } \\
\text { efficiency }\end{array}$ & $\begin{array}{l}\text { Waste water treatment facilities in the Scheldt catchment are currently being } \\
\text { improved, and the proportion of households that are connected is being increased }\end{array}$ & CIW (2008) \\
\hline $\begin{array}{l}\text { (5) Implementation of buffer } \\
\text { strips }\end{array}$ & $\begin{array}{l}\text { Buffer strips along receiving streams are considered a potentially useful means to } \\
\text { achieve nutrient retention. This measure involves wholesale implementation of buffer } \\
\text { strips along agricultural lands bordering streams. These are taken out of agricultural } \\
\text { exploitation but not bought from the owner. A proportional retention of } 57 \% \text { is } \\
\text { derived based on a median buffer width of } 15 \mathrm{~m} \text { and a median specific retention of } \\
5.4 \% \mathrm{~m}^{-1} \text {. }\end{array}$ & Vermaat et al. (2009a) \\
\hline
\end{tabular}

to be important. Thus, we associated regionalized climate change patterns of temperature and precipitation with worldwide socioeconomic scenario trajectories.

The present model allows incorporation of a range of policy measures (Table 3), which can be switched on or combined by the user. We have included substantial measures here in terms of effort needed for two reasons. First, our interest is in realistic effort needed in individual sectors to meet the set water quality target. Second, seeking the extremes helps in understanding the potential width of the policy measures. Climate scenarios and policy measures have been modeled separately because only the latter can be implemented locally, and hence, are within the grasp of policy makers. We also included a combination of several measures, which must be considered an extreme societal effort. Because agriculture is well established as a major non-point source of nitrogen in the Scheldt catchment, we identified three measures targeting this diffuse loading at two levels. At the level of farming practice, cattle density or fertilizer application can be reduced; at the level of the landscape, nitrogen retention could be enhanced by implementing buffer strips along streams, where denitrification would be maximized (Vermaat et al. 2009a). In our model runs, substantial reductions in agricultural $\mathrm{N}$ loading have been included as potential policy measures for three reasons: (1) the effects should be clearly visible in the target variable of $\mathrm{N}$ load in the river, (2) substantial reductions in fertilizer use have been realized by farmers in the recent past (Oenema 2004), and (3) zero-emission agriculture is seriously contemplated in policy (Oenema et al. 2010). Because both domestic sewer connections in towns and treatment efficiency could still be improved in the Scheldt catchment at the time of our study (Rousseau et al. 2004), this option is included as a separate policy measure. A specific efficiency and a cost has been estimated for each measure
Fig. 3. Performance of the calibrated PCRaster model of the Scheldt for different stations (13) and years (6-20). (A) Observed vs. predicted discharge (196 observations, intercept not significantly different from zero: $p=0.243$ ); (B) total nitrogen (73 observations, intercept $p=0.02$ ).
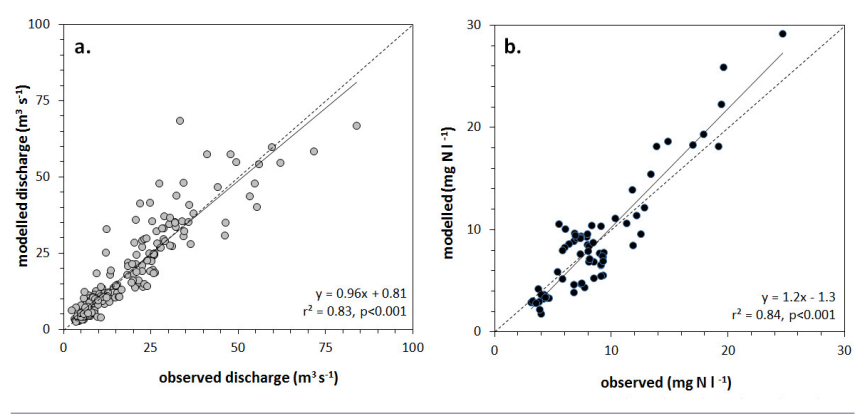

Fig. 4. Performance of the calibrated ExtendSim estuarine box model for the estuarine boxes along the Westerschelde after $1 \mathrm{yr}$ of model run (2006). The intercept did not differ significantly from zero $(p=0.21)$ and the slope is not significantly different from one $(p=0.12)$.

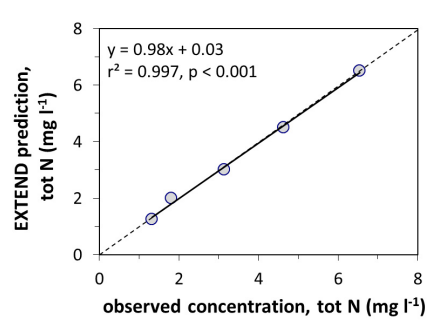


Table 4. Effects of implemented policy measures, as estimated using the PCRaster-Extend model suite in terms of load reduction at Hemiksem in 2038 and distance to water quality target as indicated by the mean summer concentration, which can be compared with the EU Water Framework Directive nitrogen standard for good ecological condition of $2.5 \mathrm{mg}$ nitrogen/L for large rivers in Flanders. Investment cost is annualized measured at a $4 \%$ interest rate over $20 \mathrm{yr}$ applying $2010 €$ values. Nitrogen concentration for the business-as-usual scenario is lower than in Fig. 6 because the 2008 values are lower than those for 2006.

\begin{tabular}{|c|c|c|c|}
\hline Policy measure & $\begin{array}{c}\text { Proportion } \\
\text { remaining of } 2008 \\
\text { load }(\%)\end{array}$ & $\begin{array}{l}\text { Total } \mathrm{N} \text { in } 2038 \\
\quad(\mathrm{mg} \mathrm{N} / \mathrm{L})\end{array}$ & $\begin{array}{c}\text { Estimated cost of measure } \\
\text { (million } € / y r ; \text { idem per percent } \mathrm{N} \text { load reduction) } \dagger\end{array}$ \\
\hline (1) Business as usual & 88 & 4.0 & Investment in manure processing plants: $396 ; 33$ \\
\hline (2) $50 \%$ cattle stock reduction & 74 & 3.4 & Net foregone farmer income: $1686 ; 65$ \\
\hline $\begin{array}{l}\text { (3) } 50 \% \text { reduction in fertilizer and manure } \\
\text { applications }\end{array}$ & 74 & 3.4 & Net foregone farmer income: $151 ; 6$ \\
\hline $\begin{array}{l}\text { (4) } 40 \% \text { improvement in waste-water } \\
\text { treatment efficiency }\end{array}$ & 47 & $2.2 \ddagger$ & Investment in infrastructure $\$: 233 ; 4$ \\
\hline (5) Implementation of buffer strips & 78 & 3.5 & Purchase of land along streams: : $56 ; 2$ \\
\hline (6) Combination of (2) to (5) & 24 & $1.9 \neq$ & N/A \\
\hline (7) Climate scenario G & 88 & 4.0 & N/A \\
\hline (8) Climate scenario $\mathrm{W}+$ & 86 & 4.3 & N/A \\
\hline
\end{tabular}

$\dagger$ Costs from Broekx and De Kok (2010).

\$The standard of $2.5 \mathrm{mg} \mathrm{N} / \mathrm{L}$ is reached in 2022 for measure (6) and in 2032 for measure (4).

§At 108-147 € population equivalent ${ }^{-1} \mathrm{yr}^{-1}$; cost and number of households connected differ between Wallonie, Flanders, and Pas de Calais.

At $1485 \mathrm{ha}^{-1} \mathrm{yr}^{-1}$ and 37,550 ha purchased by 2038 .

(Table 3), allowing flexibility in policy adoption and subsequent economic cost-benefit optimization. Current fertilizer application rates vary across the catchment, but those in Flanders are among the highest in Europe (Billen et al. 2009). This has led to a manure reallocation scheme in Flanders, which is also included in the ExtendSim module covering farmer land-use decision making.

\section{RESULTS}

\section{Model performance}

Observed annual flows and nitrogen concentrations along the riverine section as well as in the estuarine section of the Scheldt were modeled very well (Figs. 3 and 4): slopes were not different from or were very similar to unity, and intercepts did not differ from zero; hence, no systematic biases remained after calibration and verification. Also, the explained variances were high $\left(r^{2} \geq 0.83\right)$, suggesting that model predictions combined high accuracy and precision. Relative to the standards set for total nitrogen, currently reported and modeled concentrations for the majority of the sampled sites are too high. At the same, time concentrations of total $\mathrm{N}$ decline rapidly along the estuary toward the sea (Fig. 5). The estimated loading to the estuary ( 23000 ton/y, or $1100 \mathrm{~kg} \mathrm{~N} \mathrm{~km}^{-2}$ (of catchment) $\mathrm{y}^{-1}$ in the first modeled year, 2008) is well within the range estimated by Lancelot et al. (2007) or Billen et al. (2009; 1000-1600 kg N km${ }^{-2}$ (of catchment) $\mathrm{y}^{-1}$ ). Lancelot et al. (2007) estimate for the period 1990-2000 that the Scheldt
Fig. 5. Output of the ExtendSim estuarine box-model for the estuarine part of the Scheldt for business-as-usual in 2006 and for measures (2) to (5) combined in 2038 (Fig. 4). EU Water Framework Directive standards of good ecological status are $2.5 \mathrm{mg} \mathrm{N} / \mathrm{L}$ of total $\mathrm{N}$ for the river stretch and $0.46 \mathrm{mg} \mathrm{N} / \mathrm{L}$ of winter dissolved inorganic $\mathrm{N}$ (taken from the river basin management plan, RBO Schelde 2008). The latter corresponds to $0.7 \mathrm{mg} \mathrm{N} / \mathrm{L}$ of total $\mathrm{N}$ in 2006, which we used here for graphical reasons. Annual mean total nitrogen in the inflowing North Sea water from the south into the coastal zone off the Scheldt is on the order of 1.2 $\mathrm{mg} \mathrm{N} / \mathrm{L}$.

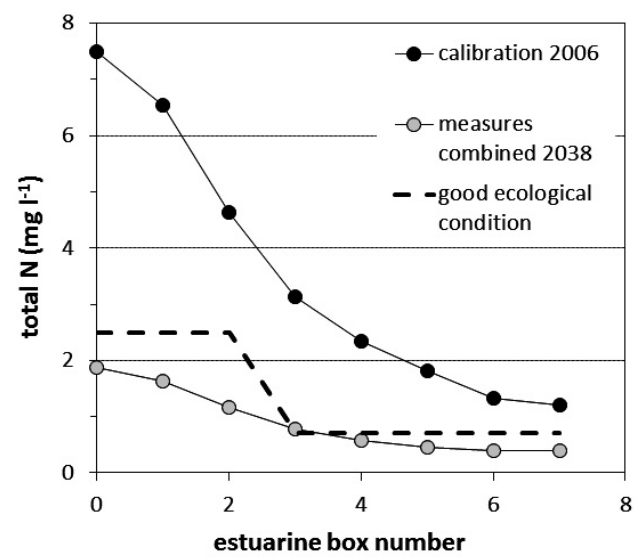


Fig. 6. Temporal development (A) and load reduction by 2038 (B) for the nitrogen load in the Scheldt at the Hemiksem station, the downstream end of the PCRaster model as a function of several policy measures, their combined effect, and two climate change scenarios. For clarity, not all measures are depicted in (A).
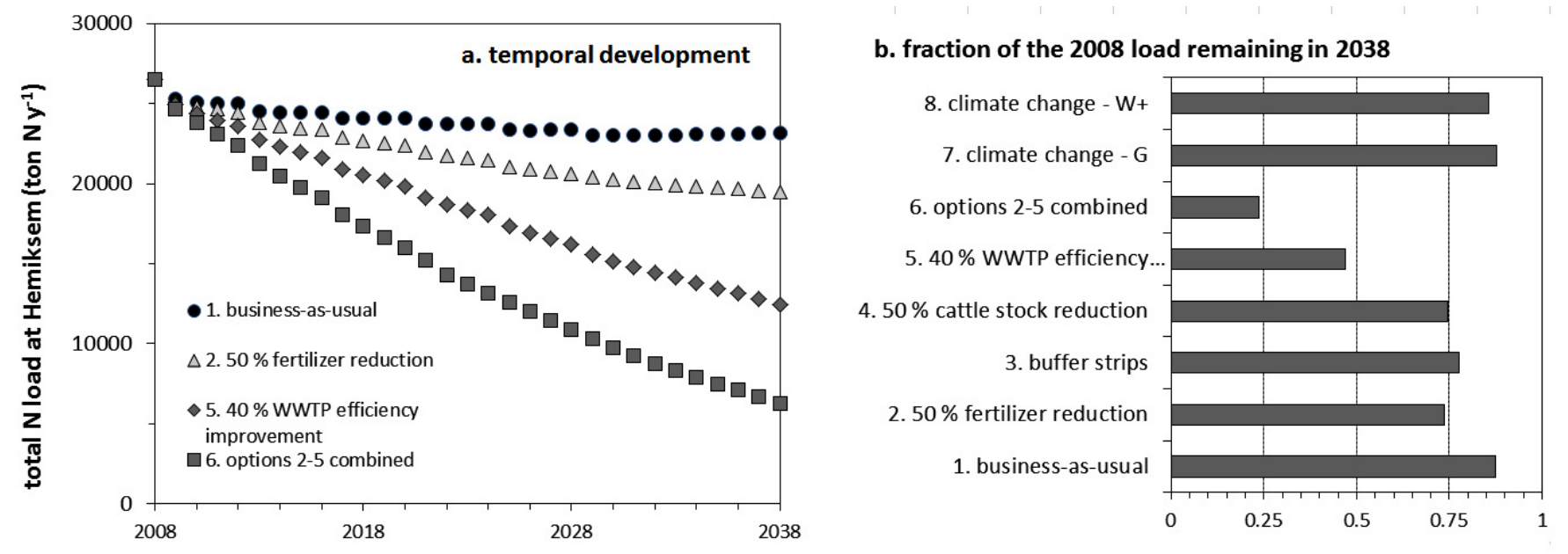

and Atlantic waters contribute approximately 20 and 30 ton $\mathrm{N} \mathrm{km}^{-2}$ (of Belgian coastal zone) $\mathrm{y}^{-1}$, respectively.

\section{Model outputs: effects of measures and scenarios}

Irrespective of the costs of the measures involved, our analyses (Fig. 6, Table 4) suggest that neither drastic cattle nor fertilizer use reduction alone would be sufficient to reduce the nitrogen load to the catchment sufficiently to lower the total nitrogen concentrations that are below $<2.5 \mathrm{mg} / \mathrm{L}$ in the riverine section. Only reduced domestic loading or a combination of measures would reduce total nitrogen concentrations below the WFD target (Table 4). The approximate $75 \%$ load reduction realized by taking all measures (Fig. 6) would significantly reduce the total nitrogen concentrations at the top of the Scheldt estuary at Hemiksem, throughout the estuary, and in the Belgian coastal zone (Fig. 5).

The two climate change scenarios, $\mathrm{G}$ and $\mathrm{W}+$, resulted in load reductions very similar to business as usual, where the $\mathrm{W}+$ scenario combined this with an increase in nitrogen concentrations, presumably coupled with a somewhat larger decrease in river discharge.

\section{Model outputs: source apportionment}

Agricultural non-point and domestic point sources are the main contributors to the total nitrogen load when we pooled across the Scheldt basin, and they are approximately equally important. Only the combined implementation of all measures (2-5) would reduce the contribution of agriculture to about one-third, but still requires most of the 30 -yr modeling period. Modeled loads under the business-as-usual scenario (Table 3) are similar to those estimated by CIW (2008) as $~ 11,000$ for households and $\sim 15,000$ for agriculture and present a gradual decline (Fig. 7) because of current investments in surplus manure processing plants that have been incorporated under business as usual. A spatial breakdown to sub-basins implies that the sub-basins of Flanders and Brussels together are presently responsible for approximately $50 \%$ of the total load and that Wallonia accounts for one-third (Fig. 8). Buffer strips appear to have the least effect in the French part of the Scheldt basin because implementation of this measure in the upstream area has little effect because the net nitrogen surplus at the soil surface is much lower than elsewhere in the basin (Fig. 8).

\section{DISCUSSION}

The satisfying verification of our model predictions against observations of flow and nitrogen concentrations in both river and estuary suggests that our model suite can be used as a credible tool for policy evaluation. We discuss some of the options available for policy makers but first argue for our application of the SAF in our specific context.

Given the initial premise supported by our stakeholder representatives, i.e., that nitrogen loading of river, estuary, and coastal waters is critical to water quality in these water bodies, and given the complicated interplay of location, type, and importance of the different sources across this international catchment, we claim that our spatial source apportionment was necessary to meet the information demand. Clearly, inland human activities have a substantial impact downstream and need to be incorporated in a decision support tool for integrated 
Fig. 7. Apportionment of the nitrogen load of the Scheldt at Hemiksem to different sectoral sources in three scenarios: business as usual, buffer strips, and options (2) to (5) combined. These three scenarios span the total range in outcomes of all scenarios (Fig. 4).
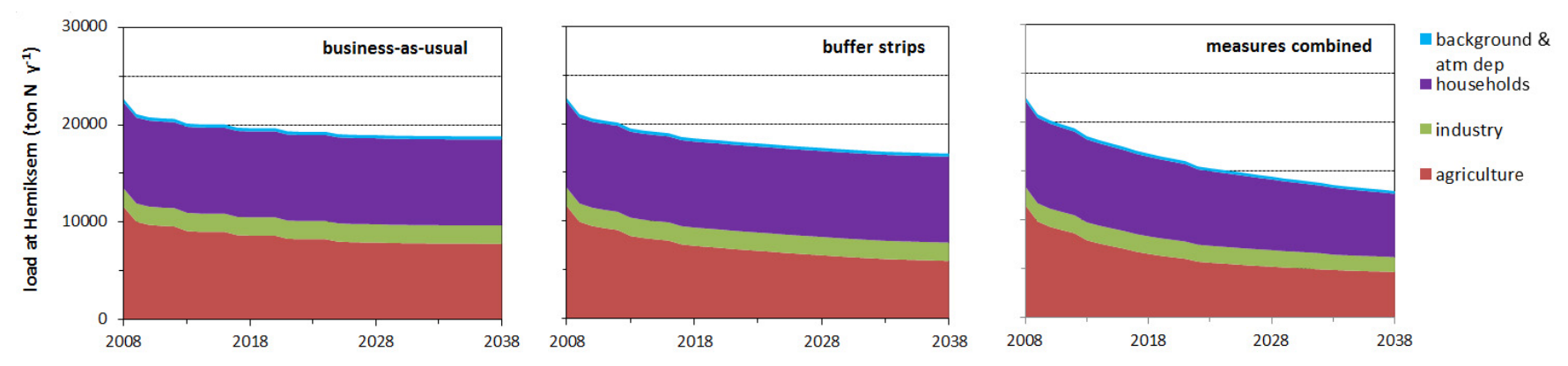

coastal zone management. Our model suite offers insight into this spatial interdependency between up-catchment nitrogen loading, policy options, climate change scenarios, and downstream nitrogen concentrations. The flexibility of the model suite is increased by the application of reusable, generic components for the measures and scenarios, which allows for quick and easy updating, expansion, or maintenance of the model (De Kok et al. 2010) and application elsewhere.

We present a variety of measures that could help reduce eutrophication in the Scheldt basin. These measures are technically achievable at moderate to major societal investments, and we provide a first estimate of their costs (Table 4, Figs. 5 and 6). It was beyond the scope of our study to include possible socioeconomic impacts in society beyond the costs of measures and the dynamics of farming systems. For example, our climate scenarios modeled plausible precipitation and temperature patterns associated with the global economic SRES scenarios but did not implement the implicit consequences of these scenarios in demography, position on world markets, or energy consumption in the regions occupying the Scheldt catchment.

Although we suggest that nitrogen load reduction could also diminish undesired Phaeocystis blooms in the downstream coastal waters based on Lacroix et al. (2007), we note that it is not yet clear to what extent the retention and internal dynamics in the estuary would be affected by changing external loads and nitrogen speciation (Soetaert et al. 2006). Because our model has annual time steps, nitrogen speciation is not included in our ExtendSim estuarine box model. There is no doubt that this estuary serves as an efficient nitrogen processing system by fueling denitrification, sedimentary retention, or both. The modeled major decline along the estuary is in agreement with the observations on the temporal development of the gradient in nitrogen concentration made by Soetaert et al. (2006). Our study of the Scheldt is a clear case in support of the classical textbook view of the estuary as a filter (Kennedy 1984). This estuarine ecosystem provides human society with the services of a natural biogeochemical reactor. In general, any human interference that may affect this functioning should be evaluated cautiously.

Our source apportionment at the freshwater-estuary boundary of Hemiksem suggests that Flanders and Wallonia are the two major contributors and that domestic point sources and agriculture still have comparable importance in the Scheldt basin. This is in distinct contrast with the majority of neighboring catchments (Seine, Meuse, Rhine, Weser, Elbe; Behrendt and Opitz 1999, Billen et al. 2001, De Wit 2001), where agriculture is currently the major nitrogen source.

Our analysis suggests that the effects of different policy measures directed on non-point agricultural sources are quite similar ( $75 \%$ of load remains after $30 \mathrm{yr}$ ), whereas a feasible and cost-efficient increase in the degree of sewage treatment would reduce the nitrogen load more strongly (to 47\%; Table 4). Also, in the business-as-usual scenario, the nitrogen load is slightly reduced. Improved sewage treatment or a combination of the modeled measures appear to be sufficiently effective to reach the WFD target (Table 4), but only over a considerable time span: after 24 yr for improved sewage treatment, and $14 \mathrm{yr}$ for the combination of measures. This is in line with the formal derogations (i.e., the European Commission's agreed-upon extension of the time to reach the WFD water quality target) requested in the river basin management plans of most regions (according to the ISC). The relative cost-efficiency of measures is only tentatively compared here, using annualized cost per proportion of load reduction (Table 4). Quite notably, the three measures of fertilizer-use reduction, improved sewage connection, and use of buffer strips appear considerably less expensive than the 
Fig. 8. Regional source apportionment of the nitrogen load of the Scheldt. Sum of the cumulative loads of the four regions exceeds the observed load at Hemiksem by 14-20\% (Figs. 4 and 6). This is probably because of uncertain estimates of water exports toward Dunkirk at the French-Belgian border and toward Western Flanders at Gent and the neglection of in-stream retention with these full-catchment instantaneous balance estimates (Olde-Venterink et al. 2003, Billen et al. 2005).
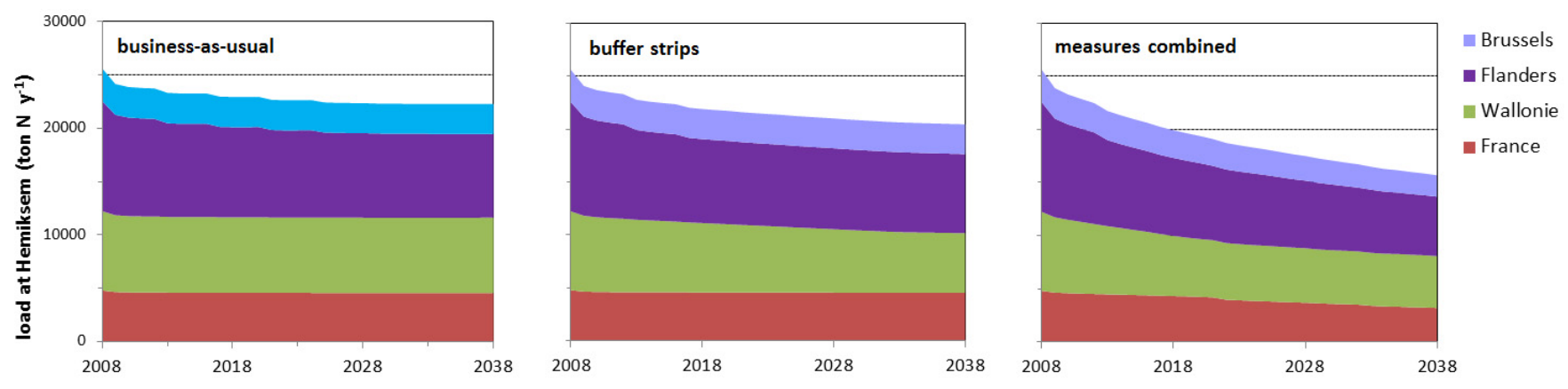

current practice of manure processing or cattle stock reduction. Only this order-of-magnitude comparison is justified because confidence intervals around our cost estimates are unknown. Nevertheless, these findings are useful in guiding policy development and decision making. Finally, our implementation of the more extreme $\mathrm{W}+$ climate change scenario does not seem to have a major effect on the nitrogen concentration in the Scheldt, at least for the 30-yr time span until 2038 (Fig. 6).

Responses to this article can be read online at: http://www.ecologyandsociety.org/voll7/iss2/art30/ responses/

\section{Acknowledgments:}

First and foremost, we thank our colleague Jeanette van Buuren at RIKZ, presently Deltares, for her energetic inputs in the scoping of this study and in our stakeholder consultation. We also thank Marcel Marchand (Deltares) for contributing to the early stages of this project and case study. Our major institutional counterparts and stakeholders, the Waterdienst in The Netherlands, VMM in Flanders, DGRNE in Wallonia, and Office de l'eau in Artois-Picardie, are thanked for sharing data and opinions with us at several stages and for contributing to our stakeholder consultation. This paper is a joint effort of the partners in case study SSA9 of SPICOSA, funded by the European Union Sixth Framework Program. This paper is dedicated to the memory of Marcel de Wit, who carried out instrumentally useful work by modeling water and nutrient fluxes in the Meuse, Rhine, and Po rivers with PCRASTER, but sadly died too early.

\section{LITERATURE CITED}

Behrendt, H., and D. Opitz. 1999. Retention of nutrients in river systems: dependence on specific runoff and hydraulic load. Hydrobiologia 410:111-122.

Berkhout, F., and J. Hertin. 2000. Socio-economic scenarios for climate impact assessment. Global Environmental Change 10(3):165-168. http://dx.doi.org/10.1016/S0959-3780(00)00029-7

Billen, G., J. Garnier, A. Ficht, and C. Cun. 2001. Modeling the response of water quality in the Seine River estuary to human activity in its watershed over the last 50 years. Estuaries 24(6):977-993. http://dx.doi.org/10.2307/1353011

Billen, G., J. Garnier, and V. Rousseau. 2005. Nutrient fluxes and water quality in the drainage network of the Scheldt basin over the last 50 years. Hydrobiologia 540(1-3):47-67. http://d x.doi.org/10.1007/s10750-004-7103-1

Billen, G., V. Thieu, J. Garnier, and M. Silvestre. 2009. Modelling the $\mathrm{N}$ cascade in regional watersheds: the case study of the Seine, Somme and Scheldt rivers. Agriculture, Ecosystems and Environment 133(3-4):234-246. http://dx.doi. org/10.1016/j.agee.2009.04.018

Breton, E., V. Rousseau, J.-Y. Parent, J. Ozer, and C. Lancelot. 2006. Hydroclimatic modulation of diatom/Phaeocystis blooms in nutrient-enriched Belgian coastal waters (North Sea). Limnology and Oceanography 51(3):1401-1409. http:// dx.doi.org/10.4319/1o.2006.51.3.1401

Broekx, S., and J. L. De Kok. 2011. Assessing costs to reduce nitrogen loads in the Scheldt basin: technical note. VITO report RMA 2011/RMA/R138. Flemish Institute for Technological Research (VITO), Mol, Belgium. 
Busch, G. 2006. Future European agricultural landscapesWhat can we learn from existing quantitative land use scenario studies? Agriculture, Ecosystems and Environment 114 (1):121-140. http://dx.doi.org/10.1016/j.agee.2005.11.007

Coördinatiecommissie Integraal Waterbeleid (CIW). 2008. Ontwerp stroomgebiedplan voor de Schelde. [Draft river basin management plan for the Scheldt]. VMM report D/2008/6871/041. Vlaamse Milieu Maatschappij (VMM), Mechelen, Belgium.

Cox, T., T. Maris, P. De Vleeschauwer, T. De Mulder, K. Soetaert, and P. Meire. 2006. Flood control areas as an opportunity to restore estuarine habitat. Ecological Engineering 28(1):55-63. http://dx.doi.org/10.1016/j.ecoleng .2006 .04 .001

Crossland, C. J., H. H. Kremer, H. J. Lindeboom, J. I. MarshallCrossland, and M. D. A. Le Tissier, editors. 2005. Coastal fluxes in the anthropocene: the land-ocean interactions in the Coastal Zone Project of the International GeosphereBiosphere Programme. Springer, Berlin, Germany.

De Kok, J. L., G. Engelen, and J. Maes. 2010. Towards model component reuse for the design of simulation models: a case study for ICZM. Pages 1215-1222 in D. A. Swayne, W. Yang, A. A. Voinov, A. Rizzoli, and T. Filatova, editors. Proceedings of the iEMSs 5th Biennial Meeting: International Congress on Environmental Modelling and Software. International Environmental Modelling and Software Society, Ottawa, Canada.

De Walle, F. B., and J. Sevenster. 1998. Agriculture and the environment: minerals, manure and measures. Kluwer, Dordrecht, The Netherlands.

De Wit, M. J. M. 2001. Nutrient fluxes at the river basin scale. I: the PolFlow model. Hydrological Processes 15(5):743-759. http://dx.doi.org/10.1002/hyp.175.abs

Drake, N. A., R. M. Blench, S. J. Armitage, C. S. Bristow, and K. H. White. 2011. Ancient watercourses and biogeography of the Sahara explain the peopling of the desert. Proceedings of the National Academy of Sciences 108(2):458-462. http://d x.doi.org/10.1073/pnas.1012231108

Ducharne, A., C. Baubion, N. Beaudoin, M. Benoit, G. Billen, N. Brisson, J. Garnier, H. Kieken, S. Lebonvallet, E. Ledoux, B. Mary, C. Mignolet, X. Poux, E. Sauboua, C. Schott, S. Théry, and P. Viennot. 2007. Long term prospective of the Seine River system: confronting climatic and direct anthropogenic changes. Science of the Total Environment 375 (1-3):292-311. http://dx.doi.org/10.1016/j.scitotenv.2006.12.011

Hopkins, T. S., D. Bailly, and J. G. Støttrup. 2011. A systems approach framework for coastal zones. Ecology and Society 16(4): 25. http://dx.doi.org/10.5751/ES-04553-160425
Kennedy, V. S. 1984. The estuary as a filter. Academic Press, Orlando, Florida, USA.

Lacroix, G., K. Ruddick, N. Gypens, and C. Lancelot. 2007. Modelling the relative impact of rivers (Scheldt/Rhine/Seine) and Western Channel waters on the nutrient and diatoms/ Phaeocystis distributions in Belgian waters (southern North Sea). Continental Shelf Research 27(10-11):1422-1446. http: //dx.doi.org/10.1016/j.csr.2007.01.013

Lancelot, C., N. Gypens, G. Billen, J. Garnier, and V. Roubeix. 2007. Testing an integrated river-ocean mathematical tool for linking marine eutrophication to land use: the Phaeocystisdominated Belgian coastal zone (southern North Sea) over the past 50 years. Journal of Marine Systems 64(1-4):216-228. http://dx.doi.org/10.1016/j.jmarsys.2006.03.010

Lautenbach, S., J. Berlekamp, N. Graf, R. Seppelt, and M. Matthies. 2009. Scenario analysis and management options for sustainable river basin management: application of the Elbe DSS. Environmental Modelling and Software 24 (1):26-43. http://dx.doi.org/10.1016/j.envsoft.2008.05.001

Lorenzoni, I., A. Jordan, M. Hulme, R. K. Turner, and T. O'Riordan. 2000. A co-evolutionary approach to climate change impact assessment: part I. Integrating socio-economic and climate change scenarios. Global Environmental Change 10(1):57-68. http://dx.doi.org/10.1016/S0959-3780(00)00012-1

Mee, L. D., R. L. Jefferson, D. d'A. Laffoley, and M. Elliott. 2008. How good is good? Human values and Europe's proposed Marine Strategy Directive. Marine Pollution Bulletin 56(2):187-204. http://dx.doi.org/10.1016/j.marpolbu $\underline{1.2007 .09 .038}$

Moll, A., and G. Radach. 2003. Review of three-dimensional ecological modelling related to the North Sea shelf system: part 1: models and their results. Progress in Oceanography 57 (2):175-217. http://dx.doi.org/10.1016/S0079-6611(03)00067-3

Mourad, D. S. J., M. Van der Perk, and K. Piirimäe. 2006. Changes in nutrient emissions, fluxes and retention in a northeastern European lowland drainage basin. Environmental Monitoring and Assessment 120(1-3):415-448. http://dx.doi.o $\mathrm{rg} / 10.1007 / \mathrm{s} 10661-005-9071-\mathrm{y}$

Nevens, F., I. Verbruggen, D. Reheul, and G. Hofman. 2006. Farm gate nitrogen surpluses and nitrogen use efficiency of specialized dairy farms in Flanders: evolution and future goals. Agricultural Systems 88(2-3):142-155. http://dx.doi.org/10.10 16/j.agsy.2005.03.005

Oenema, J., S. Burgers, J. Verloop, A. Hooijboer, L. Boumans, and H. ten Berge. 2010. Multiscale effects of management, environmental conditions, and land use on nitrate leaching in 
dairy farms. Journal of Environmental Quality 39 (6):2016-2028. http://dx.doi.org/10.2134/jeq2010.0035

Oenema, O. 2004. Governmental policies and measures regulating nitrogen and phosphorus from animal manure in European agriculture. Journal of Animal Science 82:E196E206.

Olde Venterink, H., F. Wiegman, G. E. M. Van der Lee, and J. E. Vermaat. 2003. Role of active floodplains for nutrient retention in the River Rhine. Journal Environmental Quality 32(4):1430-1435. http://dx.doi.org/10.2134/jeq2003.1430

Pieterse, N. M., W. Bleuten, and S. E. Jørgensen. 2003. Contribution of point sources and diffuse sources to nitrogen and phosphorus loads on lowland river tributaries. Journal of Hydrology 271(1-4):213-225. http://dx.doi.org/10.1016/S002 2-1694(02)00350-5

Radach, G., and J. Pätsch. 2007. Variability of continental riverine freshwater and nutrient inputs into the North Sea for the years 1977-2000 and its consequences for the assessment of eutrophication. Estuaries and Coasts 30(1):66-81.

Regionaal Bestuurlijk Overleg Schelde (RBO Schelde). 2008. Overwegingen bij het Stroomgebiedbeheerplan Schelde. [Considerations on the river basin management plan for the Scheldt]. RBO-nota 2007. Projectbureau Kaderrichtlijn Water Schelde, Middelburg, The Netherlands.

Rousseau, D. P. L., P. A. Vanrolleghem, and N. De Pauw. 2004. Constructed wetlands in Flanders: a performance analysis. Ecological Engineering 23(3):151-163. http://dx.doi. org/10.1016/j.ecoleng.2004.08.001

Small, C., and R. J. Nicholls. 2003. A global analysis of human settlement in coastal zones. Journal of Coastal Research 19 (3):584-599.

Soetaert, K., J. J. Middelburg, C. Heip, P. Meire, S. Van Damme, and T. Maris. 2006. Long-term change in dissolved inorganic nutrients in the heterotrophic Scheldt estuary (Belgium, The Netherlands). Limnology and Oceanography 51(1, part 2):409-423. http://dx.doi.org/10.4319/lo.2006.51.1 _part_2.0409

Te Linde, A. H., P. Bubeck, J. E. C. Dekkers, H. De Moel, and J. C. J. H. Aerts. 2011. Future flood risk estimates along the River Rhine. Natural Hazards and Earth System Sciences 11 (2):459-473. http://dx.doi.org/10.5194/nhess-11-459-2011

Van den Hurk, B., A. Klein Tank, G. Lenderink, A. Van Ulden, G. J. Van Oldenborgh, C. Katsman, H. Van den Brink, F. Keller, J. Bessembinder, G. Burgers, G. Komen, W. Hazeleger, and S. Drijfhout. 2006. KNMI Climate Change Scenarios 2006 for the Netherlands. KNMI Scientific Report WR 2006-012006. Royal Netherlands Meteorological Institute (KNMI), De Bilt, The Netherlands.
Verburg, P. H., C. J. E. Schulp, N. Witte, and A. Veldkamp. 2006. Downscaling of land use change scenarios to assess the dynamics of European landscapes. Agriculture, Ecosystems and Environment 114(1):39-56. http://dx.doi.org/10.1016/j.ag ee.2005.11.024

Vermaat, J.E., A. J. Gilbert, and F. Hellmann. 2009a. Riparian nitrogen retention along streams and rivers in intensively used catchments in NW Europe: technical note. IVM Report R 09/09. VU University, Amsterdam, The Netherlands. [online] URL: http://dare.ubvu.vu.nl/bitstream/1871/20921/2/R09-09. pdf.

Vermaat, J. E., W. Salomons, A. J. Gilbert, and F. Hellmann. 2009b. Articulating SRES-scenarios for use in integrated modelling of land use, hydrology and nitrogen budgets of the Scheldt catchment. IVM Report R 09/08. VU University, Amsterdam, The Netherlands. [online] URL: http://dare.ubvu. vu.nl/bitstream/1871/20928/2/R09-08.pdf. 